\title{
NEWER ADVANCES IN MESENCHYMAL STEM CELL THERAPY
}

\author{
VANITA G KANASE*, SHRUTI RAMESH SHETTIGAR
}

Department of Pharmacology, Oriental College of Pharmacy, Sector 2, Behind Sanpada Railway Station, Sanpada West, Navi Mumbai, Maharashtra, India. Email: vanita.kanase@gmail.com

Received: 08 October 2019, Revised and Accepted: 04 March 2020

ABSTRACT

In the modern world, overcoming diseases are more challenging and newer ways are being discovered to give high quality of patient care, on the basis of scientific experimentation and applicative studies undertaken by various institutes and organizations. Mesenchymal stem cells (MSCs) are procured through many body origins usually by the placenta as well as the umbilical cord but other sources like bone core derived MSCs are also important as each source will give the cells its own characteristic features. MSCs play a very important role in the scenario with their multi-lineage potency that can either directly or indirectly by acting on cytokines or growth factors can cause cell regeneration process and hold great possibility of wound repair, treating spinal cord injuries, and treating auto immune diseases by immunomodulation. MSCs can give incredible help in case of bone, cartilage or tissue related defects, injuries or disorders that may be corrected or repaired through it. They can be employed in various heart related complications, bacterial activity, sepsis, liver dysfunctions, diabetes, and even prove useful in cancer. Various procedures either physiological or surgical are present including cell therapies, tissue, and osteo-engineering and immune targeted experimentations that can treat the diseases as well as ensure complete recovery.

Keywords: Mesenchymal stem cells, Cytokines, Cardiomyocytes, Exosomes.

(c) 2020 The Authors. Published by Innovare Academic Sciences Pvt Ltd. This is an open access article under the CC BY license (http://creativecommons. org/licenses/by/4. 0/) DOI: http://dx.doi.org/10.22159/ajpcr.2020.v13i5.35999

\section{INTRODUCTION}

The human body consists of a connective tissue system that consists of connective tissue cells supporting parenchyma cells which bring about hematogenesis, the MSCs, cells such as mature bone cell, and fat cells. The three main systems of bone marrow (BM) existing are hematopoietic, endothelial, and stroma, generally based on a comparison on basis of hematogenic system, where MSCs are placed inside bone core, undergo self-renewal, and form cells transforming to many scar tissue family. Post-natal marrow stromal tissues in hematopoiesis are macrophages, osteogenic cells, adipocytes, and reticular cells [1,2]. The term, mesenchyme, is from the Greek origin that translates to "middle" (meso) "infusion" and means the ability of mesenchymatous cells to spread and migrate in early embryonic stage of development between the endodermal and ectodermal layers. An embryo containing a mesenchymal stem cell (MSC) gives rise to this pluripotent progenitor cell which will divide numerous times and whose young cells over time forms skeletal tissues such as bone, tendon, cartilage, ligament, connective tissue, and marrow stroma $[3,4]$. Types of mesenchymal progenitor cells (MPC) include BM -derived MPC, tissue-derived MPC, bone-derived MPC, cartilage-derived MPC, tendon-derived MPC, adipose tissue-derived MPC, and vascularderived MPC [5]. The possibility of the fetal membrane derived MSCs is that under several culture states, they convert to the cartilage forming, mature bone cell forming, and fat cell forming families [6,7]. Amniotic fluid as well as embryonic membrane is obtained from human secondgestational period as well as third-gestational period pregnancies with prior approval and contains various prenatal cells that initiate from many prenatal tissues, may also contain traces of maternal cells due to contamination derived from the decidua and are high in availability [8,9]. Main characteristic of MSCs is said to be multipotent because of their power, to showcase possibility to metamorphose to diversity of numerous cells/tissue families. MSCs possess finite life spans and are available all round lifespan, final quantity has inverse relation to the life time of the patient, systemic disease state, and area of withdrawal $[10,11]$. Aging of cells is defined as 'the sum of primary restrictions in regenerative mechanisms of multicellular organisms" and showing involvement of MSC in replenishment of cells and hence influencing lifespan. MSCs from geriatric patients show no spindleformed while from minor contributors show the axle structure in the very prior stage and an eventual misplacement of characteristics along the culturing period $[12,13]$. MSCs usually are separated from a draw in of bone core collected from the superior iliac crest of the pelvis in humans as well as also from the tibia along with core of femur bone sections as well as spine. Cells are usually grown in the basal medium like Dulbecco's modified Eagle's medium in the presence of $10 \%$ fetal bovine serum having a fibroblast such as structure and cohere to the tissue culture surface after distressing harm, can undergo implant, mend injured cartilage $[14,15]$. A variety of experimental states needed for favorable conversion are primary nutrition, structural arrangement, physical enforcement, cell density, and growth factors. The human MSCs grown in every transformational state will also form autocrine and paracrine components which are necessary in continuation of family $[16,17]$. After relocation in bone core of a non-fat diabetic severe combined with low immunity mice, MSCs exhibit conversion to pericapillary cells, smooth muscle such as functioning fibroblasts, bonecore matrix cells, mature bone cells, bone forming cells, and epithelial cells $[18,19]$. They exhibited additional or altered healing results in many pre-symptomatic representations of human ailments. Primary and pre-symptomatic examination utilizing MSC gives us possibility of cells among obstacles coming forth at intersection of stem cell tissue engineering, gene therapy, and science of malignancies [20,21].

\section{WOUND HEALING AND CHRONIC WOUND TREATMENT}

Non-healing persistent injuries are a huge dilemma with occurrence of 5-7 million cases per year in the United States (U.S.) and 50\% of those injuries are not healed with latest therapies, wound-care products because they lack similarity to epidermis: fusion of specific growth factors and ground substance outside cells and their proteins endogenic to the epidermis, along with operable endothelial cells, formative cells as well as MSCs. At present, schemes containing bio-engineered bandaging and cell-based products have come forth for extensive medical usage; although their results are not up to the mark due to persistent injuries posing as grave unfulfilled clinical requirement. MSCs may act through motioning of paracrine system by secreting biologically active 
molecules having effect on cell translocation, multiplication and extent of existence of surrounding cells. In particular, it is used for stubborn non-curing injuries as an outcome of distress, diabetes, vascular inadequacy, as well as various other instances. MSCs have their place in inflammatory, multiplication, and remodeling stages of injury relief, also their existence aids good bodily working toward triumphant cure. Contrast of bone core-derived MSCs versus the embryonic membrane procured MSCs exhibit minute dissimilarities in cell phenotype, metamorphosis, and immunomodulatory characteristics. Just like MSCs of other origins, embryonic membrane MSCs have high immunity, making it suitable for allogeneic use. There are three stages of injury curing, namely, inflammatory phase, proliferative phase, and remodeling phase [22-24]. BM MSC treated injuries showed faster closing of injury in genetically diabetic mice in contrast to formative cells or vehicle medium treated injuries and has exhibited increased tractile power of slit injuries in non-diabetic rats as well as has imminent work in epidermal rejuvenation $[25,26]$.

\section{TYPES OF TREATMENTS FOR CHRONIC WOUNDS}

\section{Debridement}

An imminent part of injury control is debridement, involving exclusion of external matter as well as non-viable tissues from an injury base, allowing healthy tissues to be unshielded. Systematic maintenance debridement has been introduced to activate the injury and the process of curing.

\section{Compression}

Compression regimen, done using compression bandages, is the backbone of healing for offset of ulcers in the leg. Compression bandages ask for patients to follow regularly. Latest investigation exhibited tubiform elastic bandages are a good alternative in offset of ulcers needing constant dressing renewals.

\section{Pressure-relieving devices and surfaces}

Pressure alleviating devices and exteriors (consisting beds, mattresses, and cushions) have been used to reallocate pressure as well as utilized as therapy for pressure ulcers.

\section{Negative pressure}

Negative pressure wound therapy (NPWT) separates injury emission by putting bandaging connected to a vacuum machine. It is usually not employed by itself in the curing the offset of leg ulcers. NPWT lessens swelling, elevates local insertion, lessens the bacterial load, as well as increases formation of new blood vessels as well as increases granulation tissue formation.

\section{Electrical stimulation (ES)}

ES utilizes the vibrating stream of electromagnetic energy applied to the body for curing injuries also acting as a working ancillary agent, which has been observed to increase the offset of leg ulcer and pressure ulcer curing. ES and local dry heat can work in collaboration to cure long-term diabetic ulcers.

\section{Hyperbaric oxygen therapy (HBOT)}

HBOT, revelation to $100 \%$ oxygen at a pressure $>1$ atmosphere, has been utilized in the therapy of long-term injuries. Its capacity of work can include advanced angiogenesis, lessened pro-inflammatory cytokines, as well as enhanced formation of growth factors and collagen. Latest assumption states unanticipated lessening in oxygen levels after the patient exits the HBOT chamber that can activate injury cells and enhance formation of growth factors or the enrollment of stem cells.

\section{Lasers, phototherapy, shockwaves, and ultrasound therapy}

Some examinations exhibited that the biological actions of lasers, light therapy, current, and ultrasound techniques are related to the reduction in inflammatory cells, increased fibroblast multiplication, activation of neovascularization, formation of granulation tissue, and enhanced collagen formation.

\section{Antimicrobials}

Several vein related leg ulcers are infested by bacteria. Clinical infection causes offset of leg ulcers is cured with systemic antibiotics and topical antibiotics or antiseptics, but the consistent usage of systemic antibiotics does not work. Silver-releasing bandaging is generally used. Honey is usually not useful in long-term injuries.

\section{Dressings}

Along previous 30-40 years, there has been raising favorable reception of injury bandaging which enhances moist injury curing. Usually, these bandaging consists of various pharmaceutical formulations $[27,28]$.

\section{MUSCO-SKELETAL TREATMENT}

MSCs have transformed to a main target that can prove to be possible asset in therapeutic cell-based regimens. MSCs are multi-potential cells procured from matrix tissue that has ability to multiply in mesoblast as well as endoblast cells [29]. MSCs are packed into scaffoldings in the lab which later on little period in an incubator to ensure adherence; this combination gets installed. Second, the combination is put in an incubator immersed in separation media to activate MSCs continuation to particular family; 7-14 days later, the combination was installed to orthotropic locations. The end strategy is installing scaffolds where selected cells can adhere to docking location or installing scaffolds along the included cells in preservative overlay as well as give it a chance to fully grow in vivo [30-34]. Crucial-sized ostea damages, either due to distress, malignant growth uprooting, birth defects, or sterile unfastening of correctives, generally require bone tissue relocation otherwise substitute to manage ostea strength while tendons and ligaments have limited capability to regenerate which is a challenge to tendon tissue engineering [35,36]. MSCs has ability to enhance broken bone curing process, usually by endochondral conventional hardening as well as parathyroid hormone which has part in curing bone damages through enhancing multiplication of MSCs with decreased advanced aging as well as programmed cell death [37-39].

\section{Tendon repair}

In case of hamstring restoration, similar cells, MSCs that form cartilage or ostea tissue were converted into a type I collagen gel that produces in channel surrounding resorbable suture, the terminals of which have been tied to a spring which maintains the suture under constant weight. MSCs contracted the gel and as the suture was laden, cells aligned with respect to suture. The semi contracted cell gel-suture combination was sutured into as well as oriented along the load central line within an Achilles hamstring damage in adult rabbits. During the period of 3 months, the neotissue created was a good cohesive hamstring tissue [40-42].

\section{Cell Replacement Therapy}

The BM is a highly segregated as well as complicated, multiple parts containing tissue. The maximum part is core matrix that is a multicompartment conjoining tissue that accommodated as well as promoted hematogenesis. The factor it promotes consists of creating a position that physically accommodates particular arms of the multifamily hematogenic process; both "floor space" as well as a particular micro-environment of lymphokines given by core matrix and its matrix cells $[43,44]$.

\section{Cartilage}

Damages have very restricted internal curing ability. Semi thickness related damages that do not perforate the subchondral ostea tissue do not generally restore immediately, but restoration of full thickness cartilage damages that perforate the subchondral ostea tissue is based on the situations, such as age, damage size, and site [45-47].

\section{CURRENT SURGICAL TREATMENT FOR ARTICULAR CARTILAGE INJURY}

\section{BM stimulation}

BM activation is a scheme in which subchondral ostea tissue is perforated to cause bone core-derivatized chondrocyte originators into 
the cartilage injury. Following process can also increase the appearance of lymphokines to increase cartilage restoration. This scheme consists of drilling, wearing off, and small break in bone.

\section{Mosaicplasty}

Mosaicplasty is a process where autologous osteochondral plugs are translocated to the cartilage damage site. Through this process, the restored tissue is consists majorly of hyaline cartilage. Although, contributor site morbidity and the restricted availability of autologous osteochondral plugs restrict the application of this process, mainly for restoration of large injuries [48,49].

\section{Autologous chondrocyte implantation}

In this process, osteoblast is procured from a diagnostic assay, retrieved from a non-weight bearing area of the cartilage of patients, and is extended in the lab while later injection of a suspension of extended osteoblasts is given into cartilage damages, overlayed with autologous periosteum membrane closure [50,51]. In adult pigs, it was seen that, when they were treated with MSCs injection for cartilage repair, 42 days later, there was emergence of the restored tissue in the MSCtreated group in contrast to hyaline cartilage but, in few parts and 84 days later, the contrasting features became more clear. There was significant enhancement in the quality of the restored tissue observed in the MSC treated group in contrast with two controls, also MSCs under fluorescence microscopy gave confirmation that the injected cells were located in the newly-formed cartilage and this dispersal design is the same as that of the normal cartilage [52]. Two big immune related negative prospects are connected to usage of engineered cartilage grafts. Initially, even when the quantity of the biomaterial is decreased, external matter related giant cells or granulocytes are lured by the scaffoldings or specific implanting materials and invade the hybrid tissues. Second, the engineered tissue is yet young, so cell surface or matrix protein epitopes are vulnerable. These epitopes are usually protected from the immunological action and may hence be identified as "foreign." Patients who have received cartilage grafts, exhibited antibody mediated reactions against type IX and XI collagens that are linked with collagen, type II fibrils [53].

\section{Cardiac complications}

Myocardial infarction (MI), is major reason of cardiopathy, causing loss of cardiovascular tissue as well as damaging of left ventricular function. Thus, repairing the defective myocardial tissue is required for the therapy of MI. Cellular cardiomyoplasty done by usage of needle injections is growing as a therapeutic option for patients suffering from chronic cardiopathy, though it might be restricted due to inability to rejuvenate cardiocytes. The cell sheet enables cell-to-cell linkages due to a lesser requirement for enzymatic digestion [54-56]. MSC grafts have the possibility for cardiac muscle cell multiplication as well as secrete lymphokines and growth factors that activate intrinsically mediated restoration procedures, decrease MI size and enhance cardiovascular function in pigs [57-61]. While there is ischemic heart disease in adult male Wistar inbred rats, especially in MI, main myocardial disease of losing of cardiac muscle cells and an enhancement in formative cells, is an imminent reason of cardiopathy. MSCs are not just in vitro, able of trans-segregating into functional cardiac muscle cells in special culture conditions (e.g., when treated with 5 -azacytidine) but also in vivo they segregate cardiac muscle-like cells in the acute lack of oxygen representation or in a cardiac muscle cell mass environment that shows the presence of desmin, troponin $\mathrm{T}$, adrenoceptor, and sarcomeric major histocompatibility complex (MHC) [59,62-65].

Exosomes are one of many populations of released vesicles that also consist of microvesicles, ectosomes, membrane particles, exosome-like vesicles, or programmed cell death bodies. Exosomes were found to be formed initially by sheep reticulocytes approximately 50 years ago. They have been shown to be secreted by many cell types, including B cells, dendritic cells, and mast cells. For example, protein and ribonucleic acid (RNA) in MSC exosomes were preserved from deterioration by trypsin and ribonuclease (RNase) as long as the lipid membrane was not altered. It was seen that the effectiveness of exosome uptake was linked directly with intracellular and micro-environment acid levels [66].

\section{SEPSIS}

The sepsis disease is known due to its extensive swelling, host immunological malfunction, no proper maintenance of the clot forming chain process as well as epithelial malfunction as a reaction to the intrusive infective agent. This might then further lead to septic shock, consequential multi-organ malfunction, and possibly ends in death. In sepsis, the excessive inflammatory reaction stimulates many methods that together cause the systemic reduction in blood pressure, end-organ lack of oxygen, secretion of reactive oxygen species, and pro-inflammatory lymphokines released by neutrophils and macrophages that cause end-organ injury in same amount as injury causing infective agents. MSCs in animal replicas of sepsis have made a revelation that they not only enhance organ role but also gives a survival benefit and also overall survival rate was noticeably enhanced from $10 \%$ to $50 \% 96 \mathrm{~h}$ later to cecal ligation and puncture which was done on mice that were administered intravenous MSCs [67].

\section{Spinal cord injury}

$\mathrm{SCI}$ is a distressing situation, with unanticipated loosing of sensory, motor, and autonomic function farthest to the amount of distress. Latest treatment includes surgery by decompressing as well as stabilizing the wound, avoids ancillary manifestations, management of any that does appear as well as recovery. Although its downside is that the neuro-related rehabilitation of tissues is restricted and majorly SCI patients continue to observe certain neurological malfunction and chronic damage. This therapeutic regimen gives several chances for spinal cord restoration that consists of replacement of destroying glial, neuron and related cells, once again bringing about myelination of spared axons, repair of neuron circuit, etc. MSCs have showed varying effectiveness while route of drug reaching site of action was relocated from other routes to intravenous or intrathecal means. Given all its possible advantages, there may be few drawbacks of MSCs that are documented, such as elevated chances of neoplasms in blood and elevated cancerous cell proliferation as well as its spread [68].

\section{Liver disorders}

Cirrhosis denotes end frequent disease that is the result in mainly all of long-term hepatocyte related ailments. Majorly all patients with cirrhosis lose their lives as a repercussion of many clinical obstacles that include ascite occurrence, hepatocyte related shaking brain palsy, and veinal bleeding. Hepato-translocation was observed to be most efficient therapeutic strategy for patients with progressive hepatorelated ailments. To its downside, majorly all patients are not able to procure the organ for translocation as a result of lesser availability of contributors. More than $10 \%$ of patients lose their lives in the process of receiving it for hepato-translocation. Those patients that received them, their chances of surviving were $94 \%$ at approximately 90 days, and $88 \%$ in 365 days along with $79 \%$ in 1025 days. Cirrhosis is terminal level of continual fibrosis, defined by septum formation and rings of a scar that encircle the nodules of hepatic cells. MSCs have the capability of hepatic grafting and hepatocyte multiplication, also additionally, their ability for easy access and quickly expansion characteristic in the lab makes it a perfect source for medical usage [69]. Hepatic fibroid formation has been observed to be caused due to long term hepatic damages of any form, and appears as excessive built up of extracellular matrix proteins. Long term hepato-related ailments may cause grave hepato-related malfunctions and can even be fatal like hepatic cirrhosis as well as hepatocarcinoma. Although, its practical utilization is lesser as a reason of poor chronic graft surviving capacity, lack of contributors as well as being less economic on the basis of the process. Thus, by magnetic resonance imaging, MSCs given infusion into hepatic tissues through the mesenteric vein possibly be found to be active in the fibrous hepatocyte of rats $288 \mathrm{~h}$ later to injection administration. However, in human patients, MSCs are majorly given as infusion through the veinal route. An investigation on the dispersal of MSCs after being infused has been conducted in four patients. The outcome was planar whole-body accession obtained later once infused exhibited through surrounding veinal duct and deemed safe in patients with hepatic cirrhosis [70]. 


\section{BACTERIAL INFECTIONS}

Among main effector molecules causing bacterial death are antimicrobial proteins and polypeptides that include muramidase, secretory leucoprotease inhibitor, lactoferrin, and defensins which are all capable of killing microbes. MSCs that are prior activated by Escherichia coli exhibited significant antimicrobial activity in reciprocation to $E$. coli as well as Pseudomonas aeruginosa. These outcomes point toward the point that the procedure of MSCs antimicrobial activity against Gramnegative bacteria was linked to a product released, which was installed with prior bacterial issue. Human BM derived MSCs are capable of inhibiting bacterial growth without any intermediate and the action is preserved in its conditioned medium, depicting that of a soluble factor is present. They also formed some quantity of the antimicrobial peptide, human cathelicidin (hCAP-18/LL-37), that causes inhibition of bacterial growth of E. coli as well as $P$. aeruginosa in the lab where their appearance can be induced by $E$. coli revelation both on messenger RNA and protein levels as well as in a mouse replica of $E$. coli pneumonia, MSCs administered caused noticeable decrease in bacterial counts in the bronchoalveolar lavage test [71].

\section{DIABETES}

Diabetes is caused by insulin resistance, by eventual decrease in insulin level as a result of decreased insulin sensitivity which is type 2 or by absolute lack of insulin as repercussion of autoimmune destroyed secretion of insulin from pancreatic cells which are type 1. Both types of disease include a non-optimal group of functioning cells that results in the initiation of increase in blood glucose levels and occurrence of observable disease. BM cells and MSCs together work in the cellular rejuvenation pathway. BM cells that are translocated and MSCs can take care of important factors consisting of pancreatic tissue rejuvenation as well as it has established that liver cells growth factor formed by this translocation has ability to enhance pancreatic cell rejuvenation in streptozotocin administered rats [72]. MSCs can restrict insulin type 1 diabetes through collateral effect which has influence on nerve fiber role as well as gives anti-inflammatory action which could be imminent to continue outer endurance. They can be used to cure insulin dependent diabetes by altering the immunity as well as by examination of the process initially in mice while later in small scale studies in humans [73].

\section{CANCER}

Cancer basically is the outcome of cells that uncontrollably grow which is tried to be controlled or treated by radiation or chemotherapy that has their own side effects [74]. It has already been acknowledged that immunomodulation in the treatment of various illnesses could provide an option to traditional chemotherapy [75]. For cancer, two major obstacles that limit the clinical potential are stimulation of an immune response and lack of tumor tropism of vectors. MSCs have shown to result in tumor suppression in some cases and they are comparatively easily isolated as well as extended, specifically target tumors along with metastases. This is followed by systemic delivery which takes place without interference with a range of vectors, having immune-suppressive properties and ability to express therapeutic proteins to support amplification of oncolytic viruses [76]. Adult MSCs demonstrated immense capability in the cell and gene related therapeutic implementations due to their capability for substantial selfrenovation and multi-potent nature. They were extended toward ex vivo where they were capable to multiply into cells of the existing tissue, restore defected ones and partially restore its normal function [77]. MSCs are complex delivery agents but cells with an active pathway in our body, thus they form diversity of growth factors, lymphokines, and chemokine and give pro-survival gestures for malignant cells leading to increased malignant load as well as its spread [78].

\section{IMMUNOMODULATION}

Immunomodulation is a process that has ability to alter an organism's defensive organization by intervening with its purpose of boosting the immune responses described as an immunostimulating agent that mainly acts by stimulating the non-specific system, i.e. macrophages and granulocytes [79].

MSCs that are present on the albumin exterior of the main sinusoidal blood vessels in the adult bone core produce an interlink between the surrounding and core cavity and take part in altering immunity. MSCs might jump from stimulatory to suppressive action, but it depends on the situation and has been seen to subdue immunological refusal in different species. Prior studies have exhibited that low levels of interferon gamma (IFN- $\gamma$ ) caused MSCs to show MHC-II as antigen presenting cells and higher levels of IFN- $\gamma$ mediated reduced appearance of MHC-II. Their capability was first found when they were observed and showed that they had ability to save themselves from appearing in immunosurveillance after cell translocation. Thus, they discovered its usage in steroid-refractory graft-versus-host disease. MSCs can also subdue many T lymphocyte actions both in vitro and in vivo and results in young and memory cells undergoing inhibition of the function of several immune cells through released lymphokines, growth factors, and enzymatic activity [80]. Many trials using MSCs in the treatment of autoimmune disorders in humans are currently ongoing or in the recruitment phase including Crohn's disease, multiple scleroses, ulceration and inflammation of the colon, systemic lupus erythematosus (SLE), Sjögren syndrome, systemic sclerosis, and immune-mediated severe acquired aplastic anemia [81]. SLE is a grave autoimmune ailment defined by antibodies linked multi-organ damages consisting of kidney, neuronal, cardiac, muscle, skeletal, and epidermal regions and cyclophosphamide treatment was capable to counter act on all SLE-associated changes in the liver [82].

Micro vesicles are a heterogeneous group of membrane vesicles up to 1 $\mathrm{mm}$ in size obtained from the cell membrane of human cells through the disturbance of the cortical cytoskeleton and the procedure is induced by enhanced concentrations of $\mathrm{Ca}^{2+}$ intracellular and contributes to immune activating properties [83].

\section{AUTHORS' CONTRIBUTIONS}

The authors declare that this work was done by the authors named in this article.

\section{CONFLICTS OF INTEREST}

There are no conflicts of interest.

\section{AUTHORS' FUNDING}

We thank Oriental College of Pharmacy for funding the project.

\section{REFERENCES}

1. Deans R, Moseley A. Mesenchymal stem cells: Biology and potential clinical uses. Exp Hematol 2000;28:875-84.

2. Owen M. Lineage of osteogenic cells and their relationship to the stromal system. In: Peck WA, editor. Bone and Mineral Research. Vol. 3. New York: Elsevier; 1985. p. 1-25.

3. Caplan A. Mesenchymal stem cells. J Orthop Res 1991;9:641-50

4. Somerman M, Hewitt AT, Varner HH, Schiffman E, Termine J, Reddi AH. Identification of a bone matrix-derived chemotactic factor. Calcif Tissue Int 1983;35:481-5.

5. Jose JM, Alejandro EL, Paulette C. Minireview Mesenchymal Stem Cells. United States: Pennsylvania State University; 2001.

6. Wang H, Hung SC, Peng ST, Huang CC, Wei HM, Guo YJ, et al. Mesenchymal stem cells in the Wharton's jelly of the human umbilical cord. Stem Cells 2004:22:1330-7.

7. Wang JS, Shum-Tim D, Galipeau J, Chedrawy E, Eliopoulos N, Chiu RC. Marrow stromal cells for cellular cardiomyoplasty: Feasibility and potential clinical advantages. J Thorac Cardiovasc Surg 2000;120:999-1005.

8. Anker PS, Scherjon SA, Kleijburg-van der Keur C, de Groot-Swings GM, Claas FH, Fibbe WE, et al. Isolation of mesenchymal stem cells of fetal or maternal origin from human placenta. Stem Cells 2004;22:1338-45.

9. Dang ZC, van Bezooijen RL, Karperien M, Papapoulos SE, Löwik CW. 
Exposure of KS483 cells to estrogen enhances osteogenesis and inhibits adipogenesis. J Bone Miner Res 2002;17:394-405.

10. Rocky ST, Genevieve B, Richard T. Adult mesenchymal stem cells and cell-based tissue engineering. Arthritis Res Ther 2003;5:32-45.

11. Majors AK, Boehm CA, Nitto H, Midura RJ, Muschler GF. Characterization of human bone marrow stromal cells with respect to osteoblastic differentiation. J Orthop Res 1997;15:546-57.

12. Sethe S, Scutt A, Stolzing A. Aging of mesenchymal stem cells. Ageing Res Rev 2006;5:91-116.

13. Sames K, Sethe S, Stolzing A. Extending the lifespan: Biotechnical, Gerontological, and Social Problems (Medizin and Gesellschaft). Münster, Germany: Lit Verlag; 2005.

14. Barry F, Murphy J. Mesenchymal stem cells: Clinical applications and biological characterization. Int J Biochem Cell Biol 2004;36:568-84.

15. Digirolamo CM, Stokes D, Colter D, Phinney DG, Class R, Prockop DJ. Propagation and senescence of human marrow stromal cells in culture: A simple colony-forming assay identifies samples with the greatest potential to propagate and differentiate. Br J Haematol 1999;107:275-81.

16. Pittenger M, Mackay AM, Beck SC, Jaiswal RK, Douglas R, Mosca JD, et al. Multilineage potential of adult human mesenchymal stem cells. J Electrochem Soc 1987;58:3442.

17. Manas KM, Banks V, Peluso DP, Morris EA. Isolation, characterization, and chondrogenic potential of human bone marrow-derived multipotential stromal cells. J Cell Physiol 2000;185:98-106.

18. Uccelli A, Moretta L, Pistoia V. Mesenchymal stem cells in health and disease. Nat Rev Immunol 2008;8:726-36.

19. Muguruma $\mathrm{Y}$, Yahata $\mathrm{T}$, Miyatake $\mathrm{H}$, Sato $\mathrm{T}$, Uno $\mathrm{T}$, Itoh $\mathrm{J}$, et al. Reconstitution of the functional human hematopoietic microenvironment derived from human mesenchymal stem cells in the murine bone marrow compartment. Blood 2006;107:1878-87.

20. Kumar S, Chanda D, Ponnazhagan S. Therapeutic potential of genetically modified mesenchymal stem cells. Gene Ther 2008;15:711-5.

21. Osyczka AM, Diefenderfer DL, Bhargave G, Leboy PS. Different effects of BMP-2 on marrow stromal cells from human and rat bone. Cells Tissues Organs 2004;176:109-19.

22. Maxson S, Lopez EA, Yoo D, Danilkovitch-Miagkova A, Leroux MA. Concise review: Role of mesenchymal stem cells in wound repair. Stem Cells Transl Med 2012;1:142-9.

23. Hanson SE, Bentz ML, Hematti P. Mesenchymal stem cell therapy for nonhealing cutaneous wounds. Plast Reconstr Surg 2010;125:510-6.

24. Mustoe TA, O'Shaughnessy K, Kloeters O. Chronic wound pathogenesis and current treatment strategies: A unifying hypothesis. Plast Reconstr Surg 2006;117:35S-41S.

25. Wu Y, Chen L, Scott PG, Tredget EE. Mesenchymal stem cells enhance wound healing through differentiation and angiogenesis. Stem Cells 2007;25:2648-59.

26. Du Z, Podsypanina K, Huang S, McGrath A, ToneffMJ, Bogoslovskaia E, et al. Introduction of oncogenes into mammary glands in vivo with an avian retroviral vector initiates and promotes carcinogenesis in mouse models. Proc Natl Acad Sci U S A 2006;103:17396-401.

27. Otero-Viñas M, Falanga V. Mesenchymal stem cells in chronic wounds: The spectrum from basic to advanced therapy. Adv Wound Care (New Rochelle) 2016;5:149-63.

28. Falanga V, Brem H, Ennis WJ, Wolcott R, Gould LJ, Ayello EA. Maintenance debridement in the treatment of difficult-to-heal chronic wounds. Recommendations of an expert panel. Ostomy Wound Manage 2008; $13: 14-5$

29. DiMarino A, Caplan A, Bonfield T. Mesenchymal stem cells in tissue repair. Front Immunol 2013;4:201

30. Caplan A. Adult mesenchymal stem cells for tissue engineering versus regenerative medicine. J Cell Physiol 2007;213:341-7.

31. Dennis JE, Haynesworth SE, Young RG, Caplan AI. Osteogenesis in marrow-derived mesenchymal cell porous ceramic composites transplanted subcutaneously: Effect of fibronectin and laminin on cell retention and rate of osteogenic expression. Cell Transplant 1992;1:23-32.

32. Dennis JE, Konstantakos EK, Arm D, Caplan AI. In vivo osteogenesis assay: A rapid method for quantitative analysis. Biomaterials 1998;19:1323-8.

33. Ohgushi H, Caplan AI. Stem cell technology and bioceramics: From cell to gene engineering. J Biomed Mater Res 1999;48:913-27.

34. Solchaga LA, Yoo JU, Lundberg M, Dennis JE, Huibregtse BA, Goldberg VM, et al. Hyaluronan-based polymers in the treatment of osteochondral defects. J Orthop Res 2000;18:773-80.

35. Hui JH, Ouyang H, Hutmacher D, Goh JC, Lee EH. Mesenchymal stem cells in musculoskeletal tissue engineering: A review of recent advances in national university of Singapore. Ann Acad Med Singapore 2005;34:206-12.
36. Mazock JB, Schow SR, Triplett RG. Posterior iliac crest bone harvest: Review of technique, complications, and use of an epidural catheter for postoperative pain control. J Oral Maxillofac Surg 2003;61:1497-503.

37. Wang X, Wang Y, Gou W, Lu Q, Peng J, Lu S. Role of mesenchymal stem cells in bone regeneration and fracture repair: A review. Int Orthop 2013;37:2491-8

38. Myers TJ, Yan Y, Granero-Molto F, Weis JA, Longobardi L, Li T, et al. Systemically delivered insulin-like growth factor-I enhances mesenchymal stem cell-dependent fracture healing. Growth Factors 2012;30:230-41.

39. Di Bernardo G, Galderisi U, Fiorito C, Squillaro T, Cito L, Cipollaro M, et al. Dual role of parathyroid hormone in endothelial progenitor cells and marrow stromal mesenchymal stem cells. J Cell Physiol 2010;222:474-80.

40. Arnold IC. Review: Mesenchymal stem cells: Cell-based reconstructive therapy in orthopedics. Tissue Eng 2005;11:1198-211.

41. Abbas S, Seyedjafari E, Soleimani M, Ahmadbeigi N, Dinarvand P, Ghaemi N. A comparison between osteogenic differentiation of human unrestricted somatic stem cells and mesenchymal stem cells from bone marrow and adipose tissue. Biotechnol Lett 2011;33:1257-64.

42. Seong JM, Kim BC, Park JH, Kwon IK, Mantalaris A, Hwang YS. Stem cells in bone tissue engineering. Biomed Mater 2010;5:062001.

43. Sharma RI, Snedeker JG. Biochemical and biomechanical gradients for directed bone marrow stromal cell differentiation toward tendon and bone. Biomaterials 2010;31:7695-704.

44. Ragetly G, Griffon DJ, Chung YS. The effect of Type II collagen coating of chitosan fibrous scaffolds on mesenchymal stem cell adhesion and chondrogenesis. Acta Biomater 2010;6:3988-97.

45. Koga H, Engebretsen L, Brinchmann JE, Muneta T, Sekiya I. Mesenchymal stem cell-based therapy for cartilage repair: A review. Knee Surg Sports Traumatol Arthrosc 2009;17:1289-97.

46. Fuller JA, Ghadially FN. Ultrastructural observations on surgically produced partial-thickness defects in articular cartilage. Clin Orthop Relat Res 1972;86:193-205.

47. Convery FR, Akeson WH, Keown GH. The repair of large osteochondral defects. An experimental study in horses. Clin Orthop Relat Res 1972;82:253-62.

48. Lotz M. Cytokines in cartilage injury and repair. Clin Orthop Relat Res 2001;391:S108-15.

49. Minas T, Nehrer S. Current concepts in the treatment of articular cartilage defects. Orthopedics 1997;20:525-38.

50. Minas T. Autologous chondrocyte implantation for focal chondral defects of the knee. Clin Orthop Relat Res 2001;351:S349-61.

51. Peterson L, Minas T, Brittberg M, Nilsson A, Sjogren-Jansson E, Lindahl A. Two-to 9-year outcome after autologous chondrocyte transplantation of the knee. Clin Orthop Relat Res 2000;378:212-34.

52. Lee K, Hui JH, Song IC, Ardany L, Lee EH. Injectable mesenchymal stem cell therapy for large cartilage defects-a porcine model. Stem Cells 2007;25:2964-71.

53. Risbud M, Sittinger M. Tissue engineering: Advances in in vitro cartilage generation. Trends Biotechnol 2002;20:351-6.

54. Miyahara Y, Nagaya N, Kataoka M, Yanagawa B, Tanaka K, Hao H, et al. Monolayered mesenchymal stem cells repair scarred myocardium after myocardial infarction. Nat Med 2006;12:459-65.

55. Liu J, Hu Q, Wang Z, Xu C, Wang X, Gong G, et al. Autologous stem cell transplantation for myocardial repair. Am J Physiol Heart Circ Physiol 2004;287:H501-11.

56. Reinlib L, Field L. Cell transplantation as future therapy for cardiovascular disease?: A workshop of the national heart, lung, and blood institute. Circulation 2000;101:E182-7.

57. Amado LC, Saliaris AP, Schuleri KH, St John M, Xie JS, Cattaneo S, et al. Cardiac repair with intramyocardial injection of allogeneic mesenchymal stem cells after myocardial infarction. Proc Natl Acad Sci U S A 2005;102:11474-9.

58. Pittenger MF, Mackay AM, Beck SC, Jaiswal RK, Douglas R, Mosca JD, et al. Multilineage potential of adult human mesenchymal stem cells. Science 1999;284:143-7.

59. Makino S, Fukuda K, Miyoshi S, Konishi F, Kodama H, Pan J, et al. Cardiomyocytes can be generated from marrow stromal cells in vitro. J Clin Invest 1999;103:697-705.

60. Tang, YL, Zhao Q, Zhang YC, Cheng L, Liu M, Shi J, et al. Autologous mesenchymal stem cell transplantation induce VEGF and neovascularization in ischemic myocardium. Regul Pept 2004;117:3-10.

61. Ratajczak MZ, Zuba-Surma EK, Shin DM, Ratajczak J, Kucia M. Very small embryonic-like (VSEL) stem cells in adult organs and their potential role in rejuvenation of tissues and longevity. Exp Gerontol 2008;43:1009-17. 
62. Tang J, Xie Q, Pan G, Wang J, Wang M. Mesenchymal stem cells participate in angiogenesis and improve heart function in rat model of myocardial ischemia with reperfusion. Eur J Cardiothorac Surg 2006;30:353-61.

63. Oh H, Chi X, Bradfute SB, Mishina Y, Pocius J, Michael LH, et al. Cardiac muscle plasticity in adult and embryo by heart-derived progenitor. Ann N Y Acad Sci 2004;1015:182-9.

64. Toma C, Pittenger MF, Cahill KS, Byrne BJ, Kessler PD. Human mesenchymal stem cells differentiate to a cardiomyocyte phenotype in the adult murine heart. Circulation 2002;105:93-8.

65. Shake JG, Gruber PJ, Baumgartner WA, Senechal G, Meyers J, Redmond JM, et al. Mesenchymal stem cell implantation in a swine myocardial infarct model: Engraftment and functional effects. Ann Thorac Surg 2002;73:1919-25.

66. Lai R, Chen T, Lim S. Mesenchymal stem cell exosome: A novel stem cell-based therapy for cardiovascular disease. Regen Med 2011;6:481-92.

67. Wannemuehler T, Manukyan MC, Brewster BD, Rouch J, Poynter JA, Wang Y, et al. Advances in mesenchymal stem cell research in sepsis. J Surg Res 2012;173:113-26.

68. Mothe A, Tator C. Advances in stem cell therapy for spinal cord injury. J Clin Invest 2012;122:3824-34.

69. Dai L, Li HY, Guan LX, Ritchie G, Zhou JX. The therapeutic potential of bone marrow-derived mesenchymal stem cells on hepatic cirrhosis. Stem Cell Res 2009;2:16-25.

70. Dong S, Su S. Advances in mesenchymal stem cells combined with traditional Chinese medicine therapy for liver fibrosis. J Integr Med 2014; 12:147-55.

71. Krasnodembskaya A, Song Y, Fang X, Gupta N, Serikov V, Lee JW, et al. Antibacterial effect of human mesenchymal stem cells is mediated in part from secretion of the antimicrobial peptide LL-37. Stem Cells 2010;28:2229-38.

72. Urbán V, Kiss J, Kovács J, Gócza E, Vas V, Monostori E, et al. Mesenchymal stem cells cooperate with bone marrow cells in therapy of diabetes. Stem Cells 2008;26:244-53.
73. Mounayar M, Magee C, Abdi R. Immunomodulation by mesenchymal stem cells: A potential therapeutic strategy for Type 1 diabetes. Diabetes 2008;57:1759-67.

74. Piero NM, Joan NM. Cancer: A molecular curse? Int J Curr Pharm Res 2015;7:1-3.

75. Jayaraman S, Variyar EJ. Evaluation of immunomodulatory and antioxidant activities of polysaccharides isolated from Callicarpa macrophylla Vahl. Int J Pharm Pharm Sci 2015;7:357-60.

76. Dwyer RM, Khan S, Barry FP, O'Brien T, Kerin MJ. Advances in mesenchymal stem cell-mediated gene therapy for cancer. Stem Cell Res Ther 2010;1:25.

77. Baksh D, Song L, Tuan R. Adult mesenchymal stem cells: Characterization, differentiation, and application in cell and gene therapy. J Cell Mol Med 2004;8:301-16.

78. Mohammadi M, Jaafari MR, Mirzaei HR, Mirzaei H. Mesenchymal stem cell: A new horizon in cancer gene therapy. Cancer Gene Ther 2016;23:285-6.

79. Wagle N, Nagarjuna S, Sudheer A, Roopesh C, Sapkota HP, Dangi NB, et al. Evaluation of immunomodulatory activity of petroleum ether extract of seeds of Pithecellobium Dulce in wistar rats. Int J Pharm Pharm Sci 2015;7:471-9.

80. Yagi H, Soto-Gutierrez A, Parekkadan B, Kitagawa Y, Tompkins RG, Kobayashi N, et al. Mesenchymal stem cells: Mechanisms of immunomodulation and homing. Cell Transplant 2010;19:667-79.

81. De Miguel M, Fuentes-Julián S, Blázquez-Martínez A, Pascual CY, Aller MA, Arias J, et al. Immunosuppressive properties of mesenchymal stem cells: Advances and applications. Curr Mol Med 2012;12:574-91.

82. Sun L, Akiyama K, Zhang H, Yamaza T, Hou Y, Zhao S, et al. Mesenchymal stem cell transplantation reverses multiorgan dysfunction in systemic lupus erythematosus mice and humans. Stem Cells 2009;27:1421-32.

83. Fierabracci A, Del Fattore A, Luciano R, Muraca M, Teti A, Muraca M. Recent advances in mesenchymal stem cell immunomodulation: The role of microvesicles. Cell Transplant 2015;24:133-49. 